\title{
Kovács Zsuzsa Gyöngyvér': A Debreceni Egyetem Állam- és Jogtudományi Doktori Iskola minőségbiztosítási tervének bemutatása
}

Debreceni Jogi Műhely, 2011. évi (VIII. évfolyam) 4. szám (2011. október) 21-29.

\section{Bevezető gondolatok}

Dolgozatom témája a Debreceni Egyetem Állam- és Jogtudományi Doktori Iskolája minőségbiztosítási tervének bemutatása. Mielött azonban erre rátérek, foglalkozok a minőségügy néhány elméleti kérdésével, áttekintem ennek történetét és a teljes körü minőségmenedzsment rendszerét. Figyelmet fordítok a minőségbiztosítás gondolatának megjelenésére a hazai felsőoktatás rendszerében; valamint a vonatkozó jogszabályokra és az eddigi gyakorlatra is kitérek.

Témaválasztásom indoka, hogy a hazai felsőoktatásban az elmúlt években terjedt el a minőségbiztosítás gondolata. E szemléletmód alkalmazása nemcsak az alap- és a mesterképzésekben, hanem a doktori képzésben is szükséges. Különösen fontos, ha egy új intézményröl, mint a 2006-ban elindult Doktori Iskoláról van szó.

\section{A minőségügy néhány elméleti kérdése}

\section{Történeti áttekintés}

A minőségi garancia gyökerei egészen az ókorig vezethetők vissza, erre bizonyíték a római kori ásatásokon talált hengerpecsétek, és a korsókon lévő előállítók jelei. A középkorban a mesterember rendszerint maga tervezte és állította elő a termékét és így fémjelezte produktuma minőségét. Ilyen közismert és népszerü középkori „márka” volta toledói penge és a velencei üveg. A XIII. századtól kezdve már rögzítettek bizonyos jellemzőket, így például a dél-franciaországi kendőgyártók meghatározták a termék súlyát, hosszát és büntették a gyenge minőségü gyapjú felhasználását. Hamarosan kialakultak pontos elöírások az arany és az ezüst feldolgozására is.

Az iparosodás hajnalán úgy tünt a gépi gyártás feleslegessé teszi az egyedi vizsgálatokat. A minőségi szemlélet a XIX. század végén kezdődött, amikor az Angliába importált árut már származási bizonylattal kellett ellátni.

Az I. világháborút követő gyakorlat szerint a munka minőségéért a müvezetőnek kellett felelősséget vállalni. Az általános módszer a minőség ellenőrzésére ekkor még a minden darabos vizsgálat volt. A tömeggyártás elterjedésével azonban új megoldást kellett találni, így alakult ki a mintavételes ellenőrzés, amely lényege, hogy a termék valamely tételéből reprezentatív mintát vesznek és a kapott eredményből következtetnek a teljes tételes elfogadhatóságra. Ezt a módszert a statisztika felhasználásával részletesen kidolgozták, szabványokat készítettek és ma is használják. Néhány ágazatban azonban, mint amilyen az elektronika minimális hibahányad sem engedhető meg. Ebben az esetben a gyártási folyamat ellenőrzése jelentett megoldást. A XX. század második felében terjedtek el a dokumentált minőségszabályozási rendszerek, amelyeket minőségbiztosítási rendszereknek nevezünk. Ebben jelentős helyet foglaltak el a minőségügyi szabványrendszerek pl.: az 1979-es BS-5750 számú brit minőségügyi szabványrendszer, amely az ISO 9000 előfutára volt. Ezt követően került sor a Fehér Könyv publikálására, amely hangsúlyozta a szabványosítás fejlesztését a független tanúsítási és nemzeti akkreditációs rendszer kialakítását.

1947-ben jött létre a Nemzetközi Szabványügyi Szervezet (ISO), amelynek eredményei olyan megállapodásokban jelennek meg, amelyek nemzetközi szabványok létrehozatalához 
vezetnek. A szabványfejlesztési munka egyik közismert darabja az ISO 9000, amelyet később az Európai Szabványügyi Testület is adaptált, létrehozva ezzel az Európai Közösség jövendő egységes piacának harmonizált minőségbiztosítási rendszer szabványát.

Hazánkban a minőségügyi szabályozás megteremtése az elmúlt két évtized eredménye. Kiemelést érdemel a minőségügyről szóló 3545/1992. sz. kormányhatározat, amely az EK. minőségügyi szempontjait ülteti át a magyar jogba. A 2006/1993. sz. kormányhatározat a legfontosabb kormányzati feladatokat rögzíti, így a nemzeti szabványozás, a tanúsító intézetek, a Nemzeti Minőségügyi Program megvalósításával kapcsolatos kormányzati koordinációt. A minőségüggyel kapcsolatban az országgyülés is több törvényt alkotott pl.: a nemzeti szabványosításról szóló 1995. évi XXVIII. törvényt és az ellenőrző szervezetek akkreditálásáról szóló 1995. évi XXIX. törvényt. E jogszabályok szellemében megkezdte müködését a Magyar Szabványügyi Testület, és a Nemzeti Akkreditáló Testület. Rohamosan terjed az ISO 9000 szerinti minőségbiztosítási rendszerek bevezetése, a kisvállalkozások felkészítésére regionális forrásokat is létrehoztak. ${ }^{2}$

\section{A teljes körü minőségmenedzsment (TQM) elemei}

Ez a minőségirányítás egy olyan szemléletet jelent, amelynek alapelemei:

- a vevő megelégedettsége

- az erőforrások hatékony felhasználása

- a folyamatos javítás

- a dolgozók személyi fejlődése

- megfelelö szervezés

- a minőségjavítási eszközök alkalmazása

A rendszer alapelvei közül ki kell emelni a vevőközpontúságot, vagyis azt az elvet, hogy a vevők igényeit minden alkalommal ki kell elégíteni ahhoz, hogy a szervezet a célját megvalósíthassa. Fontos a folyamatok javítása is, amelynek célja, hogy minden esetben megbízható folyamatok jöjjenek létre, a kívánt kimenet valósuljon meg, mindenféle eltérés nélkül. A harmadik alapelv a teljes elkötelezettség, amely azt jelenti, hogy az intézmény vezetőit megfelelően irányítani kell, és olyan intézkedéseket kell szorgalmazni, amely hasznosítja a szervezet valamennyi alkalmazottjának tehetségét. Mindezek segítségével a vállalat piaci előnyre tesz szert.

A TQM modelljének kiegészítő elemei is vannak:

- vezető szerep: a szervezet vezetőinek saját példájukkal elől kell járniuk és elismerésben részesíteni azokat, akik sikeresen alkalmazzák a minőségmenedzsment koncepcióját.

- Fontos az alkalmazottak oktatása és képzése, hiszen ezek hozzájárulnak a hatékonysághoz és a minőség javításához, a szervezeten belüli közös nyelv és közös eszköztár használatához.

- Támogató struktúrák bevezetésére is szükség van, ilyen lehet egy külső szakértő alkalmazása.

- Elvárás a megfelelő kommunikáció is, hiszen az összes munkatárssal meg kell értetni a változás iránti elkötelezettség fontosságát.

- Jutalmazásban és elismerésben kell részesíteni a TQM-et sikeresen alkalmazó csoportokat és egyéneket, ez föleg a korai stádiumban lehet fontos.

- Alapvető elem a mérés és az adatok felhasználása, amelyek a szubjektív vélemények helyébe lépnek. A vevőkre vonatkozó adatok gyüjtése arra sarkallja a dolgozókat, hogy valódi problémákkal foglalkozzanak. ${ }^{3}$ 


\section{Minőségbiztosítás a felsőoktatásban}

Az 1993. évi felsőoktatási törvény 80. §-a rendelkezik elöször minőségbiztosítási követelményekről, amikor rendelkezik a Magyar Akkreditációs Bizottság létrehozásáról. „A felsőoktatásban a képzés, a tudományos tevékenység színvonalának folyamatos ellenörzésére és a minösités elvégzésére a Kormány Országos Akkreditációs Bizottságot hoz létre". ${ }^{4}$ Az 1993-as felsőoktatási törvény egyik módosítása, a 2000. évi XCVII. törvény rendelkezett először a felsőoktatási minőségbiztosítási rendszerröl., azonban midössze annyit ír e kérdésről, hogy „a felsőoktatási intézmény Szabályzatában a felsőoktatás minöségpolitikai követelményrendszerének megfelelöen meghatározza minöségbiztositási rendszerét". 5 A hatályos, 2005. évi CXXXIX. Tv. Az elérendő célok között említi „a felsőoktatási intézmény minőségbiztositási és minőséghitelesitési rendszerének fejlesztésével annak biztositása, hogy a felsöoktatási intézmények a hazai és a nemzetközi munkaeröpiacon hasznositható, magas színvonalú és továbbfejleszthetö ismereteket közvetitsenek hallgatóik részére". 6

Az elmúlt években a minőségbiztosítási rendszerrel kapcsolatban az alábbi tapasztalatok születtek.

Negatív vélemények:

- a kapacitás, a kompetencia hiánya és az adminisztrációs nehézségek miatt a rendszer negatív fogadtatásban részesült

- nehézséget okozott az adatkezelés technikai erőforrásainak hiánya és a költségek fedezetének biztosítása

- probléma adódott az integrálódott karok területi széttagoltságából

- a speciális modellek hiánya miatt szükséges volt a minőségügyi gondolkodásmód elsajátítására

Pozitív tapasztalatok:

- rendszeressé váltak az önértékelések

- az intézmények müködése szabályozott és racionális lett

- sikerült mérhető eredményeket felmutatni

- sor került a hatáskörök pontosítására

- fejlödött a kommunikáció és a külső-belső kapcsolatok

- fejlödött a tervezés folyamata

- állandóvá vált a fejlesztés és a korszerüsítés. ${ }^{7}$

A minőségbiztosítási rendszer megvalósításának három eleme van:

- az akkreditációs politika átalakulása minőségbiztosítási politikává, amiben az állami és önkormányzati minőségbiztosítási politika nyújt segítséget

- erős minőségi orientáció megvalósítása, részben motivációval (pl.: minőségi díj odaítélésével), részben tanácsadással, ajánlások kidolgozásával

- a felsőoktatásból eddig hiányzó intézményi minőségbiztosítási eljárások és szervezeti feltételek kialakítása. ${ }^{8}$

Megállapítható, hogy az ellenérzések erősebbek a felsőoktatásban, mint a versenyszférában, mert itt még nincs egységes rendszer és követendő példa.

Az új szabályozásnak meg kell határoznia a minőségfejlesztési program tartalmát, az ütemterv elkészítését, a Felsőoktatási Minőségi Díj müködtetését.

A MAB is segíthet az intézményeknek, többek között:

- helyi konzultációval

- elvárások, követelmények tisztázásával 
- kérdöívek feldolgozásához szükséges szoftverek biztosításával

- követendő példák megjelölésével és azok terjesztésével

- a minőségügy szerepének tisztázásával az akkreditációban. ${ }^{9}$

\section{A Debreceni Egyetem Állam- és Jogtudományi Doktori Iskola minőségbiztosítási} tervének bemutatása

A dolgozat e fejezetéhez a Debreceni Egyetem Állam- és Jogtudományi Doktori Iskola Minőségbiztosítási Tervét, valamint Debreceni Egyetem Állam- és Jogtudományi Doktori Iskola Müködési Szabályzatát használtam fel.

\section{Minőségbiztosítási alapelvek}

A Doktori Iskola minőségbiztosítási rendszere az alábbi elvek szerint müködik:

- nyilvánosság, átláthatóság, folyamatos dokumentálás elve

- szakmai kontroll és a visszacsatolás elve: a doktoranduszok és az oktatók, témavezetők munkájának értékelése, a tevékenység színvonalának folyamatos visszajelzése

- minőségközpontúság és a tudományetikai követelmények érvényesülésének elve

- az értekezések gyakorlati alkalmazhatóságának elve.

A minőségbiztosítási feladatok koordinációját a Doktori Iskola vezetője látja el. A minőségbiztosítási feladatok megoldása részben a képzésben részt vevő oktatók és témavezetők, részben az adminisztratív feladatokat intéző doktori titkár munkáján keresztül történik. ${ }^{10}$

\section{A minőségirányítási rendszer főbb elemei}

A minőségbiztosítási terv fontosnak tartja a képzési tárgyak tartalmának folyamatos megújítását, a tudomány legújabb eredményeinek megjelenítését a képzés során. Ennek megfelelően a tananyagok tartalmát a Doktori Iskola Tanácsa kétévente értékeli.

A Doktori Iskolába történő felvételnél biztosítékokat kell teremteni a doktoranduszok minőségi munkáját illetően. Ezért követelmény egy középfokú „C” típusú államilag elismert nyelvvizsga, legalább cum laude minősítésű jogi diploma, illetve más kapcsolódó szakterületen szerzett mesterszaknak megfelelő diploma. A felvétel követelménye az átgondolt kutatási program is. ${ }^{11}$

A nappali tagozatos $\mathrm{PhD}$ hallgatók száma kettő és négy fő között mozog. A Doktori Iskola megindulásának első éveiben nem volt jellemző a túljelentkezés, a létszámkeretet sikerült betölteni. 2009-ben és 2010-ben viszont többen jelentkeztek nappali tagozatra, az addigi három-négy fó helyett kilencen-tízen is pályáztak. Elmondható, hogy akik nem nyertek felvételt nappali tagozatra, levelező képzésben folytathatták tanulmányaikat.

A felvételi követelmények az alábbi táblázatban foglaltam össze: ${ }^{12}$

\begin{tabular}{|l|l|l|}
\hline I. szakmai intelligencia & nappali tagozat & $\begin{array}{l}\text { levelező } \\
\text { és egyéni képzés }\end{array}$ \\
\hline $\begin{array}{l}\text { felvételi beszélgetés (előadó- } \\
\text { és vitakészség) }\end{array}$ & 15 & 15 \\
\hline szakmai nyelvi beszélgetés & 5 & 5 \\
\hline $\begin{array}{l}\text { kutatási terv és vázlat } \\
\text { (témaismeret, koncepció) }\end{array}$ & 20 & 20 \\
\hline
\end{tabular}

\begin{tabular}{|l|l|lr|}
\hline $\begin{array}{l}\text { II. diploma (végzettség, } \\
\text { gyakorlat) }\end{array}$ & nappali tagozat & $\begin{array}{l}\text { levelezö } \\
\text { és egyéni képzés }\end{array}$ & tagozat \\
\hline
\end{tabular}




\begin{tabular}{|l|l|l|}
\hline $\begin{array}{l}\text { summa cum laude 1. (4,81- } \\
5,00)\end{array}$ & 30 & 30 \\
\hline $\begin{array}{l}\text { summa cum laude 2.(4,51- } \\
4,80)\end{array}$ & 25 & 25 \\
\hline cum laude 1.(4,01-4,50) & 15 & 15 \\
\hline cum laude 2.(3,51-4,00) & 10 & 10 \\
\hline szakvizsga kzakjogászi & - & 7,5 \\
\hline $\begin{array}{l}\text { Másoddiploma, kutatási } \\
\text { végzettség }\end{array}$ & 20 & 7,5 \\
\hline $\begin{array}{l}\text { tudományos } \\
\text { gyakorlat }\end{array}$ & 20 \\
\hline
\end{tabular}

\begin{tabular}{|l|l|l|}
\hline $\begin{array}{l}\text { III.eddigi tudományos } \\
\text { munka }\end{array}$ & nappali tagozat & $\begin{array}{l}\text { levelezö } \\
\text { és egyéni képzés }\end{array}$ \\
\hline $\begin{array}{l}\text { megjelent vagy megjelenésre } \\
\text { igazoltan elfogadott } \\
\text { publikáció(k) }\end{array}$ & 10 & 20 \\
\hline $\begin{array}{l}\text { OTDKI-III. helyezés vagy } \\
\text { különdíj }\end{array}$ & 20 & 20 \\
\hline helyi TDK I-III. helyezés & 15 & 15 \\
\hline $\begin{array}{l}\text { részvétel helyi vagy OTDK } \\
\text { konferencián vagy azzal } \\
\text { egyenértékü tudományos } \\
\text { rendezvényen helyi vagy }\end{array}$ & 10 & 10 \\
\hline $\begin{array}{l}\text { opponencia helán } \\
\text { OTDK konferencián }\end{array}$ & 5 \\
\hline demonstrátori tevékenység & 10 & 10 \\
\hline $\begin{array}{l}\text { egyéb elismert tudományos } \\
\text { eredmény }\end{array}$ & 5 & 15 \\
\hline
\end{tabular}

\section{Kimeneti követelmények, amelyek a minőségbiztosítás alapját képezik}

1. A képzési- kutatási terv egyénre szabottan, a témavezetővel egyeztetve kerül kialakításra. Az aktuális kutatási tervet minden félév elején el kell készíteni, szem előtt tartva az értekezés majdani megvédését. Ez a terv segít a kutató munka állásának rendszeres ellenőrzésében.

2. A képzés során alkalmazott számonkérések között az esszék élveznek elsőbbséget, a szóbeli vizsgák ritkán fordulnak elö. A dolgozatok biztosítják a doktoranduszok írásbeli elemző, értékelő, kifejező készségének fejlődését. Fontos szempont, hogy a képzésben részt vevő ne csak saját kutatási témájában mélyüljön el, hanem más szakterületeken, jogágakban is otthonosan mozogjon. E követelmények érvényesítése mellett -amennyiben arra lehetőség van-, az oktatók biztosítják a doktoranduszok számára a kutatási témájukhoz kapcsolódó témájú házi dolgozat megírását.

3. A doktori képzés alatt, szemeszterenként egy alkalommal a doktorandusznak kötelező minősítésen, a kutatási fórumon kell átesnie, amelynek során a Doktori Iskola Tanácsa értékeli az előrehaladást, valamint a doktorandusz és a témavezető teljesítményét. A fórumon a hallgatók a többi doktorandusz és a tapasztalt oktatók elött számolnak be eredményeikről. A programon kötelezö a megjelenés. A fórum lehetőséget ad a kutatási eredmények folyamatos megvitatására. 
A minőségbiztosítás eszköze, hogy a jelölteknek a védésig megfelelő számú és minőségü publikációval kell rendelkezniük. Előny az idegen nyelven, különösen a külföldi folyóiratban történő megjelenés. A publikációk alkalmasságát a védésre bocsátás feltételeként a Doktori Iskola Tanácsa értékeli.

Publikációk értékelésének szempontjai a doktori iskolában az alábbiak szerint történik:

\begin{tabular}{|l|l|}
\hline \multicolumn{2}{|l|}{ Konferencia-előadások } \\
\hline magyar nyelven, Magyarországon & 3 kredit \\
\hline idegen nyelven, Magyarországon & 4 kredit \\
\hline idegen nyelven, külföldön & 6 kredit \\
\hline
\end{tabular}

Előadásanyag (legalább 20.000 leütés terjedelem esetén) konferencia-kiadványban

\begin{tabular}{|l|l|}
\hline magyar nyelven & 2 kredit \\
\hline idegen nyelven, Magyarországon & 3 kredit \\
\hline idegen nyelven, külföldön & 4 kredit \\
\hline
\end{tabular}

Tanulmány, szemlecikk, könyvfejezet (legalább 20.000 leütés terjedelem esetén)

\begin{tabular}{|l|l|}
\hline magyar nyelven & $3-6$ kredit/iv (a közlöhely rangossága szerint) \\
\hline idegen nyelven & $4-8$ kredit/ív (a közlöhely rangossága szerint) \\
\hline
\end{tabular}

\begin{tabular}{|l|l|}
\hline \multicolumn{2}{|l|}{ Egyéb publikációs tevékenység } \\
\hline magyar nyelvü recenzió & 2 kredit \\
\hline idegen nyelvű recenzió & 3 kredit \\
\hline idegen nyelvű recenzió külföldön & 4 kredit \\
\hline technikai szerkesztés & 1 kredit \\
\hline
\end{tabular}

Kiemelkedően rangos publikáció esetén a Doktori Iskola vezetője a fenti kreditszámoktól pozitív irányba, az egyébként adható kreditszám 1,5-szöröséig eltérhet.

Terjedelmi szempontok:

- $\quad 30$ ezer leütésig : $\quad$ 0,5 ívnek megfelelő kreditszám számolható el;

- 30-50 ezer leütésig: 1 ívnek megfelelő kreditszám számolható el;

- 50-70 ezer leütésig: 1,5 ívnek megfelelő kreditszám számolható el;

- 70-90 ezer leütésig: 2 ívnek megfelelő kreditszám számolható el;

- és így tovább.

4. Hazai és nemzetközi oktatási, tudományos és kutatási kapcsolatok. A kar ösztönzi és támogatja a doktoranduszok hazai és külföldi tapasztalatszerzését, részvételét hazai és nemzetközi konferenciákon. A Doktori Iskola Tanácsa a tudományos konferenciákon való szereplés alapján krediteket adhat. A gyakorlatban bármely konferencián történő szereplés krediteket biztosít a doktorandusz számára. A részvételi díjat és az utazási költségeket a Doktori Iskola megtéríti.

5. A szigorlatra bocsátás (azaz az abszolutórium megszerzésének) feltétele, hogy a jelölt a Doktori Iskola szabályzatában meghatározott számú és megoszlású kreditekkel rendelkezzék. Ennek megfelelően a jelöltnek 180 kredittel kell rendelkeznie, amelyböl 
45 kredit származhat oktatási tevékenységből. A kreditpontok gyüjtésére a képzés 6 félévének lezárását követően még egy évig lehetőség van, de ebben az időtartamban csupán tudományos, publikációs tevékenységre lehet kreditet elszámolni.

Az abszolutórium megszerzésének másik feltétele, hogy a hallgató rendszeresen részt vegyen kutatási fórumokon. $\mathrm{Az}$ is szükséges, hogy a kutatási témában való előrehaladást a témavezető minden félévben igazolja.

6. A levelező képzésben részt vevőkre vonatkozó követelmények minden szempontból megegyeznek a nappali tagozatos doktoranduszokra vonatkozó követelményekkel, eltekintve attól, hogy a képzéseken való rendszeres megjelenésük alól munkahelyi megterhelésük miatt néhány alkalommal felmentést kaphatnak. A gyakorlatban azonban csak kivételesen fordul elö, hogy egy levelezős hallgató látogatja az előadásokat. A tantárgyak teljesítésének egyéb feltételei azonban megegyeznek nappali és levelező tagozaton, hiszen mindenkinek kell szóbeli, vagy írásbeli beszámolót készíteni. A gyakorlatban további eltérés, hogy a levelező tagozatosoknak nem kell részt venniük a nappalisok számára kötelező programokon, mint többek között a nyilvános-, és mühelyviták. A kutatási fórumon való megjelelés alól azonban a levelezős hallgatók sem kaphatnak felmentést.

7. Az egyéni felkészüléssel fokozatot szerezni kívánók habitusvizsgálaton esnek át. Ezt a vizsgálatot a Doktori Iskola Tanácsa végzi. Egyéni képzésre az vehető fel, aki egyetemi diplomával és tudományos eredményekkel, publikációkkal rendelkezik. A feltételek meglétét a Doktori Iskola vezetőjének javaslatára a Doktori Iskola Tanácsa állapítja meg. Ezeknek a hallgatóknak a védésre bocsátáshoz szigorlatot kell tenniük.

8. A Doktori Iskola hangsúlyt fektet a témavezető és a doktorandusz közötti szoros együttműködésre. Ennek megfelelően a témavezető köteles a jelölt fejlődését elősegíteni, előrehaladását nyomon követni, tudományos-, és kutatási kapcsolatait előmozdítani. Minőségbiztosítási szempontból az együttmüködés alábbi elemeit kell kiemelni

- a témavezetönek minden szemeszter végén egy leckekönyvi bejegyzés formájában igazolnia kell, hogy a hallgató teljesítette a kutatási feladatot. Ezzel a témavezető elismeri, hogy a doktorandusz a témáját vele a félév során konzultálta, és kutatásában előrehaladást mutat.

- Az értekezés benyújtásához szükséges, hogy a témavezető az első oldalon aláírásával igazolja hozzájárulását az értekezés benyújtásához.

9. Végzett $\mathrm{PhD}$. hallgatók pályakövetése: az Educatio Kht. PhD. módszertana alapján szakmai és munkaerö-piaci karriervizsgálatot kell készíteni, és vizsgálni kell a doktori képzésről kialakult véleményeket, elvárásokat és változtatási javaslatokat. Szükséges az eredmények figyelembevétele a képzési struktúra és a képzési tartalmak változtatásában.

A karon még nem készült felmérés a végzett $\mathrm{PhD}$. hallgatók pályakövetéséről. A Doktori Iskola 2006-ban kezdte meg a müködését, kutatásaim szerint az Educatio Kht. utolsó ilyen irányú vizsgálata 2005-ben történt.

Az elmúlt években a Doktori Iskola 5 ,évfolyamot” indított, ebböl 2 évfolyam fejezte be eddig a képzést. 2009-ben 1 fő szerzett abszolutóriumot, 2010-ben 5 fö, 2011. első felében pedig 2 fö. E hallgatók közül ketten szereztek fokozatot, mindketten a kar fóállású tanársegédei.

10. Fontos a fokozatot szerzett $\mathrm{PhD}$. hallgatók fórumának kialakítása is. Ilyen konferenciák megszervezésére azonban nem került sor. A karon a korábbi években diplomát szerzett, és - főként - az oktatásba bekerült hallgatók a DI megalapítása előtt a Miskolci Egyetemen, a Deák Ferenc Doktori Iskolában végezték PhD. 
tanulmányaikat, és szereztek fokozatot. Részvételükkel megvalósítható lenne a fokozatot szerzett hallgatók konferenciája, hiszen a végzettek csekély száma miatt erre néhány évig kevés esély lesz. ${ }^{13}$

\section{IV. Összegzés}

A doktori képzés pontjai és azok dokumentumai az alábbiakban foglalhatóak össze: ${ }^{14}$

\begin{tabular}{|l|r|}
\hline Minőségmérés pontjai & Dokumentumok \\
\hline szabályzatok, meghirdetett & - múködési szabályzat \\
felülvizsgálata & - képzési terv \\
& - aktuális témakírások \\
\hline az oktatási folyamat értékelése & - kutatási fórum anyagai \\
& - témavezető beszámolója \\
& - kérelem \\
& - leckekönyv \\
\hline publikációk pontozása & - szigorlati jkv. \\
\hline a fokozatszerzés dokumentumainak elemzése & - munkahelyi védés jkv-e \\
& - nyilvános védés jkv-e \\
\hline
\end{tabular}

A Doktori Iskola minőségbiztosítási terve ezeket az elemeket tartalmazta a minőségirányításra és a minőség garantálására vonatkozóan. Ezt a rendszert megfelelőnek tartom, azonban megítélésem szerint a hallgatók kutatásának irányítását egyéb módon is meglehetne valósítani, illetve a kutatási eredményeiket más fórumokon is meg lehet vitatni. Az eredmények ismertetésének bevett helye a minden félévet lezáró kötelező fórum. Lehetne azonban ennek egy könnyedebb, de szintén nagyon hasznos kiegészítője. A karon jól müködő intézmény a kutatói teadélután, ahol a már fokozatot szerzett, tapasztalt oktatók adják elő legújabb eredményeiket. Ezeknek a programoknak megvalósítható lenne egy junior tagozata, ahol kötetlenebb formában szólhatnak hozzá a doktoranduszok kutatásához a kollegák. A megfelelö felkészülés is biztosított lenne, hiszen a kutatási fórummal ellentétben nem csak a Doktori Iskola vezetője, hanem az előzetesen e-mailban elküldött dolgozatnak köszönhetően az összes érdeklődő megismerhetné és tanulmányozhatná a megvitatásra váró anyagot.

Dolgozatomban bemutattam a Debreceni Egyetem Állam- és Jogtudományi Doktori Iskola minőségbiztosítási tervét. A fentiek alapján megállapítható, hogy a terv biztosítja a Doktori Iskola minőségének megőrzését, és az oktató- kutató utánpótlás fenntartását. A tantárgyak sokszínűsége, a kutatás eredményeinek megvitatási lehetőségei, a kutatási terv és a publikációk biztosítják az értekezés majdani sikeres megvédését.

\section{Felhasznált irodalom jegyzéke:}

\section{Könyvek, cikkek, tanulmányok}

1. Igaz Jenő - Kardos Károly- Pintér József- Solecki Levente (2000.): Minőségügy, SZIF UNIVERSITAS Kft., Győr

2. Polónyi István (2006.): A munkaerőpiacra orientált felsőoktatási minőségbiztosítás. In.: Bálint Julianna - Polónyi István - Siklós Balázs: A felsőoktatás minősége FKI, Budapest 
3. Polónyi István (2007.): Minőségmenedzsment alapjai, Kossuth Egyetemi Kiadó, Debrecen.

4. Puskás Orsolya (2008.): A Debreceni Egyetem minőségbiztosítási rendszerének továbbfejlesztési lehetőségei, Szakdolgozat, Debreceni Egyetem Közgazdaságtudományi Kar, Debrecen

5. Szekeres Péter (2004.): Minőségbiztosítási rendszerek a magyar felsőoktatási intézményekben, a MAB 2004. évi kutatás-fejlesztési projektjének tanulmányai, Budapest

\section{Jogszabályok, egyéb:}

1. 2005. évi CXXXIX. törvény

2. 2000. évi XCVII. törvény

3. 1993. évi LXXX. törvény

4. Debreceni Egyetem Állam- és Jogtudományi Doktori Iskola Minőségbiztosítási Terve http://www.law.klte.hu/ (letöltés idöpontja: 2011. 05. 02.)

5 .

\footnotetext{
${ }^{1} \mathrm{PhD}$ hallgató, DE-ÁJK.

${ }^{2}$ Igaz Jenő-Kardos Károly- Pintér József- Solecki Levente (2000.): Minőségügy, SZIF UNIVERSITAS Kft., Győr, 2-7. o.

${ }^{3}$ Polónyi István (2007.): Minőségmenedzsment alapjai, Kossuth Egyetemi Kiadó, Debrecen, 49-51.o.

${ }^{4}$ 1993. évi LXXX. tv. 80-81. §

${ }^{5}$ 2000. évi XCVII. tv 6. $\S$

${ }^{6}$ 2005. évi CXXXIX. tv.2. § (1)

${ }^{7}$ Szekeres Péter (2004.): Minőségbiztosítási rendszerek a magyar felsőoktatási intézményekben, a MAB 2004. évi kutatás-fejlesztési projektjének tanulmányai, Budapest, 124-131. o.

${ }^{8}$ Polónyi István (2006.): A munkaerőpiacra orientált felsőoktatási minőségbiztosítás. In.: Bálint Julianna Polónyi István - Siklós Balázs: A felsőoktatás minősége FKI, Budapest, 10-32 o.

${ }^{9}$ Puskás Orsolya (2008.): A Debreceni Egyetem minőségbiztosítási rendszerének továbbfejlesztési lehetőségei, Szakdolgozat, Debreceni Egyetem Közgazdaságtudományi Kar, Debrecen, 16. o.

${ }^{10}$ Debreceni Egyetem Állam- és Jogtudományi Doktori Iskola Minőségbiztosítási Terve

${ }^{11}$ Debreceni Egyetem Állam- és Jogtudományi Doktori Iskola Minőségbiztosítási Terve

12 http://www.law.klte.hu/ (letöltés időpontja: 2011. 05. 02.)

${ }^{13}$ Debreceni Egyetem Állam- és Jogtudományi Doktori Iskola Minőségbiztosítási Terve

${ }^{14}$ Debreceni Egyetem Állam- és Jogtudományi Doktori Iskola Minőségbiztosítási Terve
} 